\section{ANNALS OF THE UNIVERSITY OF CRAIOVA}

Series: $\begin{aligned} & \checkmark \text { Biology } \\ & \checkmark \text { Horticulture } \\ & \checkmark \text { Food products processing } \\ & \text { technology } \\ & \checkmark \text { Environmental engineering }\end{aligned}$

Vol. XXVI (LXII) - 2021

\title{
ABUNDANCE AND DYNAMICS OF APHIDS COLLECTED FROM POTATO CROP USING YELLOW-PAN TRAPS AND SUCTION TRAP
}

\author{
Bărăscu Nina ${ }^{1}$, Donescu Daniela ${ }^{1}$, Donescu Victor ${ }^{1}$, Petre Diana $^{1}$ \\ ${ }^{1}$ National Institute of Research and Development for Potato and Sugar Beet Braşov, Romania \\ ${ }^{*}$ Correspondence author E-mail:nina.barascu@gmail.com
}

Keywords: aphids, potato crop, virus vector

\begin{abstract}
This paper presents data on the abundance, dynamics and diversity of aphid species collected with yellow pan traps and the suction trap on potato crops. Aphids (greenfly, blackfly, plant louse) are an extremely important group of pests that limit crop productivity by causing severe damage either directly, by feeding on plant sap, or indirectly as vectors of the most important viruses. The main damage to the aphid crop of seed potatoes is due to the spread of phytopathogenic viruses. Production losses due to infections with potato leaf roll virus (PLRV) can vary between $53-81 \%$ and for potato virus $Y(P V Y)$ between $33-89 \%$, depending on the abundance and structure of aphid populations, potato variety, infection rate, vegetation stage and year-specific climatic conditions. A total of 4102 specimens of 113 different species were collected and identified. The large number of specimens and species collected in 2020 with suction trap (3180 from 108 species) compared to the yellow pan traps (922 from 65 species) is noticeable.
\end{abstract}

\section{INTRODUCTION}

The potato (Solanum tuberosum L.) is one of the most important crops globally, an industry in itself and a vital food source. Crop quality and productivity are closely linked to the phytosanitary status of the seed potato and the degree of virus infection. Important tuber-borne potato diseases include, among many, aphidborne afflictions. Although a relatively small group of insects, aphids are a severe problem for agriculture. Of the 4400 (according to some researchers, 5000) known species of the Aphididae family, 450 are endemic to crop plants, and 100 have successfully exploited the agricultural environment. Of these, over 50 species are direct pests of seed potato crops (Blackman \& Eastop 2007; van Emden \& Harrington, 2007; Surwan, 2019.) The ability of aphids to rapidly exploit ephemeral habitats makes them serious pests, resulting from their high reproductive potential, dispersal ability and adaptability to local survival.

Potato viruses are the most dangerous diseases. On the one hand, this is because they virtually do not respond to treatments; on the other hand, the viruses accumulate in all subsequent generations of tuber production. Disturbances of growth processes, deformation of the leaf apparatus and tubers lead to reduced yield and product quality and, subsequently, to degeneration of varieties. 
Three elements are needed to trigger virotic infections: host plant, virus and vector. In this trinomial, the vector allows the virus to be detected and spread from one plant to another. The epidemiology of aphid-transmissible viral diseases must be examined as an interactive effect between each element of the trinomial and the multitude of disturbing factors acting on each component. Each host plant-virusvector relationship appears as a unique event. Depending on the mode of acquisition and retention period, aphids transmit potato viruses from diseased to healthy plants in four ways: non-persistent; semi-persistent; persistent and circulating and persistent and propagating (Nault 1997; Whitfield et al. 2015).

Insect monitoring is mainly done with yellow pan traps with water and detergent that attract most aphid species or with/and suction traps. The traps are analyzed and the species present in the field, which pose a virological threat to seed potato crops, are identified. The use of suction traps has allowed for advanced knowledge and prediction of aphid migration over large areas and long periods of time. There is an extensive network of suction traps worldwide. Their most significant advantage over yellow pan traps is that the samples correlate positively with the actual amount of each aphid species in flight. In contrast, yellow pan traps capture relatively few of the species that are not attracted by yellow.

Compared to suction traps, yellow pan traps provide more localized (and more recent) information on how aphids fly in or close to seed potato crops. Although the results obtained with yellow pan traps focus on aphid species that transmit potato viruses (and are conducted for a shorter period), data are obtained on a broader range of aphid species, including cereal aphids, crops in rotation with potatoes. These results can help build a picture of regional aphid risk to crops as part of broader aphid monitoring.

\section{MATERIAL AND METHODS}

During 2020, aphid populations in the potato crop in Brasov were monitored using two types of traps: yellow pan water traps and suction trap (Fig.1).

The mode of operation of the yellow pan traps and suction traps and the interpretation of the data obtained in an extensive network have been published by Robert, 1981; Robert \& Janvry, 1977; Robert et al., 1974; Taylor, 1981).

Yellow pan traps were placed in potato crops planted with Castrum and Asinaria varieties at distances of 20,50 and $80 \mathrm{~m}$ from the edge. The traps, round in shape and $28 \mathrm{~cm}$ in diameter, were filled with water and liquid detergent added to prevent the insects from flying away. The yellow traps were placed in the crop immediately after potato sprouting. The traps were raised gradually to always be at the same level with the vegetation and visible to the aphids during crop growth.

The suction trap consists of two components: a $9.2 \mathrm{~m}$ plastic tube mounted on a $3 \mathrm{~m}$ concrete box containing the electrical, filtration and catch storage equipment. The suction tube is mounted on a parallelepiped construction in which the suction and capture systems of the suction stroke are mounted. The tube is anchored to the ground with eight-point lashings to ensure wind resistance. The trap sucks in a standardized air volume of $0.75 \mathrm{~m}^{3} / \mathrm{sec}$ from a height of $12.2 \mathrm{~m}$ and extracts aphids and other small insects into a collection jar with water and alcohol.

The yellow pan traps and suction trap, ran from May to September 2020. The catches allowed us to understand the population structure, abundance and flight dynamics of aphids. Samples were collected daily until 9 am, sorted and preserved in $70^{\circ}$ alcohol until species identification. 

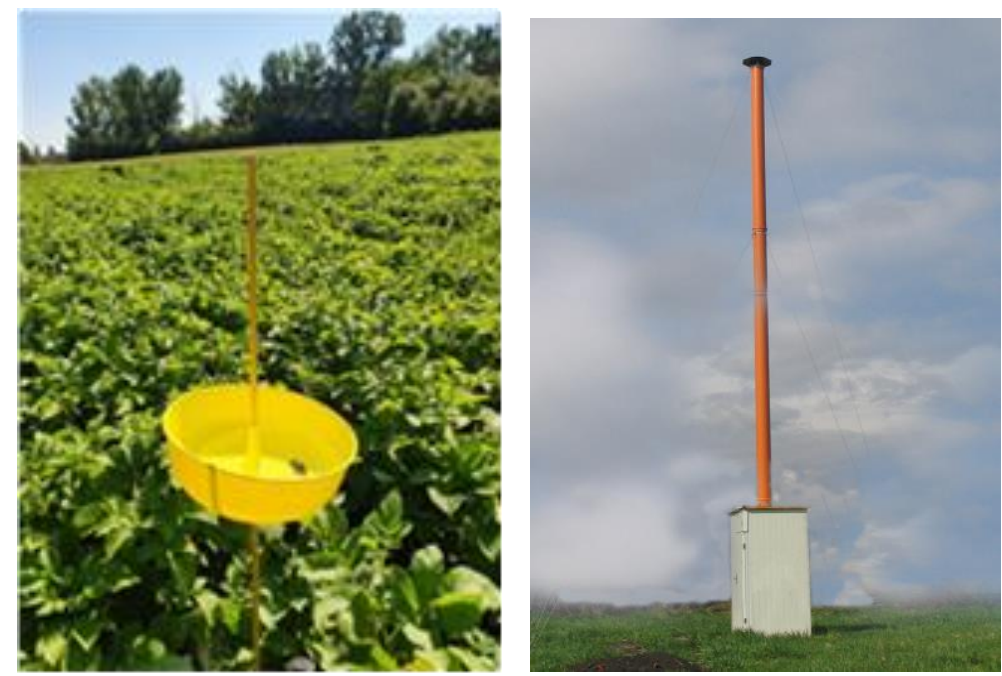

Figure 1. Yellow pan water trap and suction trap

The collection of biological material in plastic containers and aphids caught with the two types of traps was sorted from other insect groups and identified. The following morphological characters were considered for the identification of the captured aphid species: length, color and shape of the body, particular characters of the head and antennal tubercles (bumps on the head housing the base of the antennae), of the thorax, abdomen and its appendages, size and color of the cornicles (cylindrical structures at the end of the abdomen), length of the antennae, compared to the length of the body, length of the tail compared to that of the cornicles, abdominal markings, degree of sclerotization, nature of the cuticular surface, size and shape of the brush or setae, the shape of the wing veins. A series of winged aphid identification keys were used for accuracy of identification and systematic classification. (Blackman \& Eastop 2007, Jacky et Bouchery 1982, Leclant 1999, Nieta-Nafria et al. 1999, Remaudière \& Remaudière 1997, Taylor 1981). Captured aphids were identified using a stereoscopic microscope (Motic).

The abundance of the different species identified on the yellow pan traps placed at different distances from the edge of the potato field and those caught by the suction trap was calculated for each species, decadal, monthly and total.

\section{RESULTS AND DISCUSSIONS}

In the potato crop from Brașov, 4102 aphids classified in 113 species were collected and identified in the two types of traps during the monitoring period (May September 2020). The dynamics and abundance of aphids captures from the yellow traps and the suction trap at Brașov in 2020 is presented in figure 2.

In the yellow pan traps - 922 aphids $(22,47 \%$ of the total catches) were classified in 65 species; in the suction trap - 3180 aphids (77,52\% of the total) in 108 species. The high number of specimens and species caught in the suction trap compared to the yellow traps is remarkable.

Between May and September, catches from the yellow pan traps had the following dynamics: May - 375 aphids (27 species); June - 360 (43 species); July 106 (26 species); August - 23 (14 species); September - 58 (19 species). 

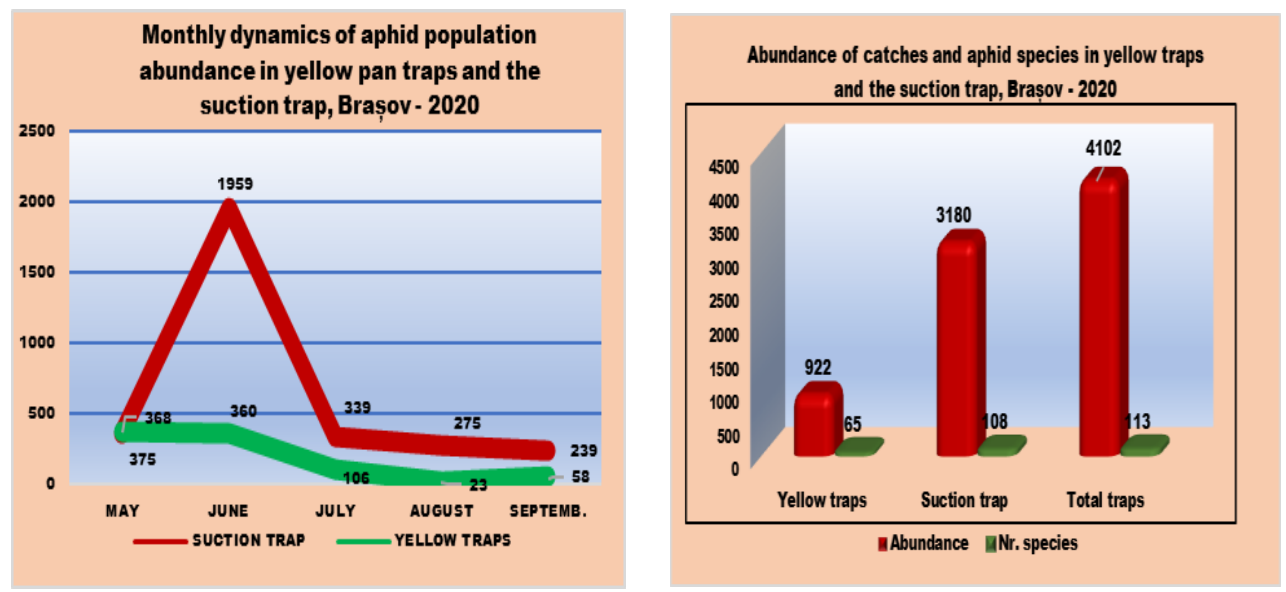

Figure 2. The dynamics and abundence of aphids captures from the yellow traps and the suction trap (Brasov, 2020)

The suction trap recorded a population of 3180 aphids classified into 108 species. This is practically the most abundant population recorded in 2020 and also the highest number of species identified. The month with the most abundant catches was June, with a total of 1959 aphids (95 species). This is followed by a drastic reduction in aphid abundance in the next interval. The other months recorded much lower populations compared to June: May - 368 aphids ( 33 species); July - 363 aphids (52 species); August 275 aphids ( 31 species) and September 239 aphids ( 35 species). It should be noted that intense aphid activity at the beginning of the potato growing season poses a significant virological risk to the crop.

The abundance of aphids according to the distance of the yellow pan traps from the edge of potato crop revealed the following aspects: in May, the most abundant were the catches of V2 trap located $50 \mathrm{~m}$ from the edge of the field (145 aphids) and V3 at $80 \mathrm{~m}$ (131 aphids); in June V2-128 aphids; V3- 122 aphids. In the following three months (July-September), catches in the three yellow pan traps were significantly reduced. Contrary to expectations, more aphids were not collected in the trap located at the edge of the potato crop $(20 \mathrm{~m})$ but inside the crop at $50 \mathrm{~m}$ from the edge, respectively $80 \mathrm{~m}$.

Of the abundant species (Figure 3), seven are potential virus vectors (Phorodon humuli (Schrank), Hyalopterus pruni (Geoffroy), Brevicoryne brassicae (L.), Aphis craccivora Koch, Brachycaudus helichrysi (Kaltenbach), Myzus persicae (Sulzer), Aphis fabae Scopoli. They have totaled 462 specimens in the yellow traps (50.10\%); 1392 in the suction trap (43.77\%); and 1854 specimens $(45.19 \%)$ of the total species identified. Almost half of the collected aphids were represented by species with viroid potential.

The main virotic vector in seed potatoes is the species Myzus persicae Sulz. which efficiently transmits all types of viruses with major phytosanitary implications on potato quality. The dynamics of its abundance in the two traps are different (Figure 4). 


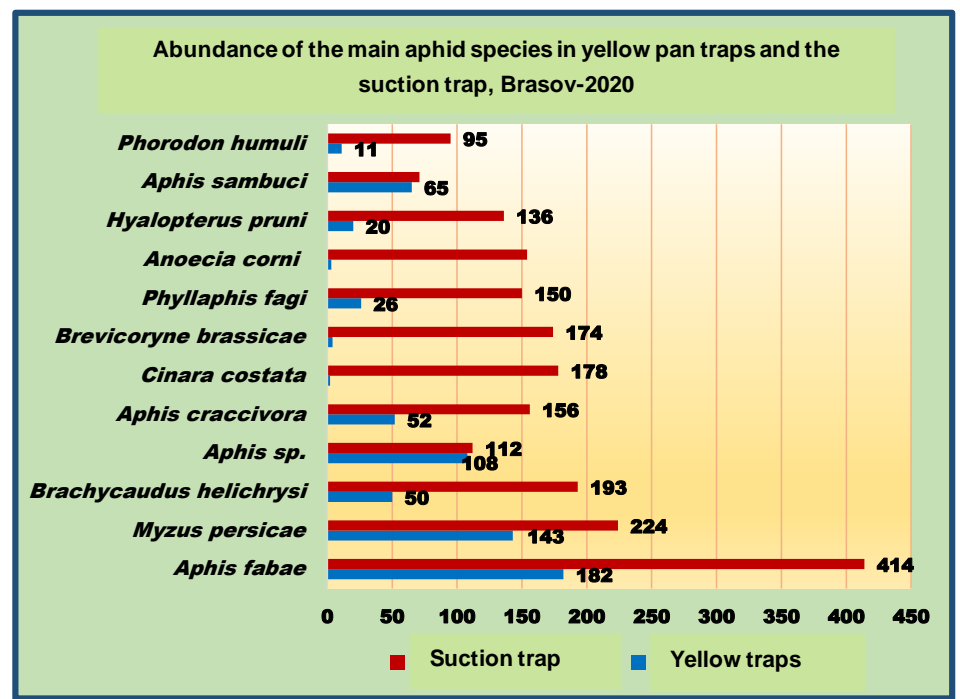

Figure 3. The abundance of the main aphid species in yellow traps and suction trap

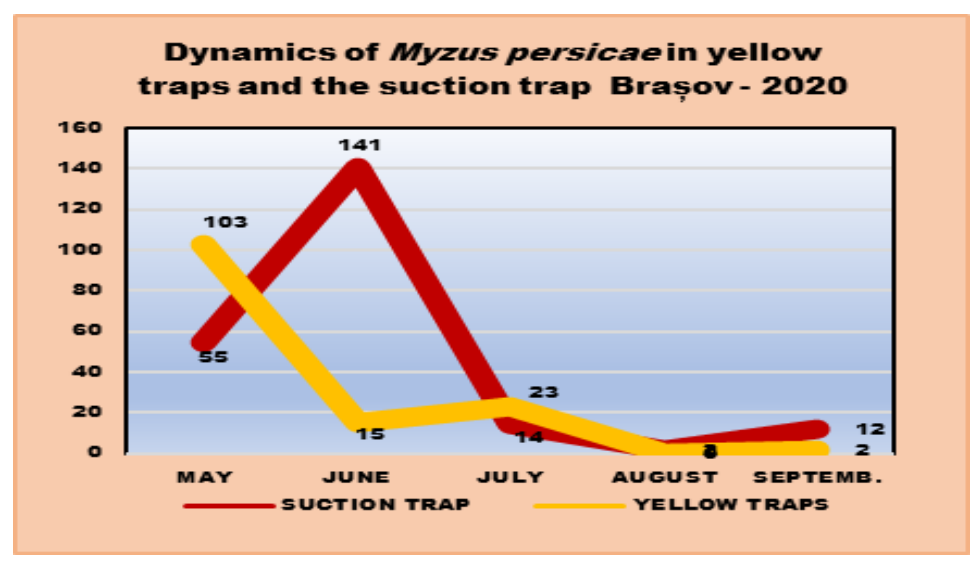

Figure 4. Dynamics of Myzus persicae captured in yellow traps and suction trap

Relatively high populations were collected in yellow pan traps in May (103 individuals), after which there was a drastic reduction in aphid activity.

In the suction trap many aphids were caught in June (141) after which the populations also declined greatly. The explanation for the high abundance of the species in the first two months of potato growing may be the mild winter temperatures which allowed the species to survive in good conditions. The summer months were quite capricious with heavy rainfall and high temperatures which limiting activity.

\section{CONCLUSIONS}

Monitoring the activity, abundance and diversity of aphid populations in potato crops using two types of traps revealed the following aspects:

- a total of 4102 individuals of 113 different species were collected and identified. 
- yellow pan traps - 922 aphids (22.47\% of the total catch) classified in 65 species; - the suction trap - 3180 aphids $(77.52 \%$ of the total) of 108 species.

- of the abundant species, 7 are potential vectors of viruses to potato (Phorodon humuli (Schrank), Hyalopterus pruni (Geoffroy), Brevicoryne brassicae (L.), Aphis craccivora Koch, Brachycaudus helichrysi (Kaltenbach), Myzus persicae (Sulzer), Aphis fabae Scopoli.

- they totalled 462 specimens in the yellow pan traps (50.10\%); 1392 in the suction trap (43.77\%); 1854 specimens $(45.19 \%)$ of the total species identified.

- almost half of the catches were represented by aphid species with virotic potential in seed potato crops.

- the suction trap recorded much more abundant catches and a higher diversity of aphid species compared to the yellow pan traps.

\section{ACKNOWLEDGMENT}

The paper was published under the frame of Programme ADER 2019-2022, project 522/2019, Ministry of Agriculture and Rural Development, România

\section{REFERENCES}

Blackman, R.L., Eastop, V.F., 2007. Taxonomic Issues. Pages 1-3 in H.F. van Emden et R. Harrington (éds.), Aphids as Crop Pests. CAB International, Cambridge, MA, É.-U.

Jacky, F., Bouchery. Y., 1982. Atlas des formes ailées des espèces courantes de pucerons. INRA, Colmar, France.

Leclant, F., 1999. Les Pucerons des plantes cultivées. Clefs d'identification. Tome II: Cultures maraîchères. Éditions INRA, ACTA, Paris, France.

Nault L. R., 1997. Arthropod transmission of plant viruses: A new synthesis. Annals of the Entomological Society of America, 90, 521-541.

Nieta-Nafria, J., Latteur, G., Durante, M.M., Tahon, J., Hidalgo, N.P., 1999. Les pucerons de Belgique (Hemiptera: Aphididae). Parasitica 55: 5-38.

Remaudière, G., Remaudière M., 1997. Catalogue des aphididae du monde. Éditions QUAE, Versailles, France.

Robert, Y., 1981. The operation of yellow water traps and suction traps and the interpretation of the data collected, in: L.R. Taylor (ed.), Euraphid Rothamsted1980, Rothamsted Experimental Station, Harpenden, pp. 28-32.

Robert, Y., Choppin de Janvry, E., 1977. Sur l'intérêt d'implanter en France un reseau de piegeage pour ameliorer la lutte contre les pucerons, Bull. Tech. In! Min. Agric. 323:559-568.

Robert, Y., Rabasse, J.M., Rouzé-Jouan, J., 1974. Sur l'utilisation des piéges jaunes pour la capture de pucerons en culture de pomme de terre. I. Influence de la hauteur de piegeage, Ann. Zool. Ecol. Anim. 6:349-372.

Surwan, K., 2019. Aphid-Plant Interactions: Implications for Pest Management.

Taylor, R.A.J., 1981. The behavioural basis of redistribution I. The delta-model concept. The Journal of Animal Ecology, 1981 - JSTOR.

Van Emden, H. F., Harrington, R., 2007. Aphids as Crop Pests. Centre for Agriculture and Bioscience International, London.

Whitfield, A.E'Falk, B.W., Rotenberg, D., 2015. Insect vector-mediated transmission of plant viruses. Virology; 479-480:278-89. 